\title{
Assessing Factors Contributing to the Prevalence of Protein-Energy Malnutrition Among Children Under Five Years of Age Attending Kigoma District Hospital, Tanzania
}

\author{
Ejike Daniel Eze ${ }^{1, ~ *}$, Ambrose Barasa ${ }^{1}$, Moses Dele Adams², Karimah Mohammed Rabiu, \\ Emmanuel Tiyo Ayikobua ${ }^{1}$, Iliya Ezekiel ${ }^{4}$, Quadri Khadijah Kofoworola ${ }^{5}$, \\ Alfred Omachonu Okpanachi ${ }^{1}$
}

${ }^{1}$ Department of Physiology, Faculty of Biomedical Sciences, Kampala International University, Western Campus, Ishaka, Uganda

${ }^{2}$ Department of Biochemistry, Faculty of Science and Technology, Bingham University, Karu, Nigeria

${ }^{3}$ Department of Biological Sciences, Faculty of Science, Yobe State University, Damaturu, Nigeria

${ }^{4}$ Department of Biological Sciences, Faculty of Pure and Applied Sciences, Federal University, Wukari, Nigeria

${ }^{5}$ Department of Physiology, College of Medicine, University of Lagos, Lagos, Nigeria

Email address:

daniel.ejike@kiu.ac.ug (E. D. Eze)

${ }^{*}$ Corresponding author

\section{To cite this article:}

Ejike Daniel Eze, Ambrose Barasa, Moses Dele Adams, Karimah Mohammed Rabiu, Emmanuel Tiyo Ayikobua, Iliya Ezekiel, Quadri Khadijah Kofoworola, Alfred Omachonu Okpanachi. Assessing Factors Contributing to the Prevalence of Protein-Energy Malnutrition Among Children Under Five Years of Age Attending Kigoma District Hospital, Tanzania. Journal of Food and Nutrition Sciences. Vol. 6, No. 5, 2018, pp. 123-128. doi: 10.11648/j.jfns.20180605.12

Received: September 9, 2018; Accepted: September 28, 2018; Published: November 6, 2018

\begin{abstract}
Protein-energy malnutrition (PEM) is a form of malnutrition that is common in children under 5 years of age in the developing countries and even the developed countries. Young children are the most vulnerable to the vicious cycles of malnutrition, infection and disability, all of which influence the present condition of a child and the future human resource development of the nation as a whole. The prevalence of PEM in the children under five years of age has been shown not to witness a great improvement in Tanzania. It even increased in some districts including Kigoma District. Thus, this research was designed to assess the factors contributing to the high prevalence of PEM in children under 5 years of age in Kigoma District Hospital of Tanzania. This study was a cross-sectional study that involved randomly selected 100 women, who had children under 5 years of age. The women and their children were assessed for their nutritional status and the factors that affect the nutritional status. The results showed a high prevalence of PEM in the children under 5 years of age as shown by the clinical symptoms such as poor weight gain, slowed linear growth, behavioral changes, anemia, muscle wasting, peripheral edema, glossitis, cheilosis, sparse hair and nail spooning. The poor socioeconomic status that might have resulted from poverty was also indicated. The high prevalence of PEM in Kigoma District could be due to infections and low educational status of the mother resulting in poor nutritional status of their children.
\end{abstract}

Keywords: Protein-Energy Malnutrition, Educational Status, Infection, Kigoma District, Anemia

\section{Introduction}

Malnutrition is a health concern in developing countries $[1,2]$ characterized by deficiency in both macro and micro nutrient intake and increased frequency in the occurrence and attack by infectious bacterial and fungal diseases [3, 4].

Protein-energy malnutrition (PEM) is the most serious form of malnutrition with infants and young children being most susceptible to its characteristic growth impairment because of their high energy and protein needs [5]. Largesized families, poverty, illiteracy and infection due to helminths are mainly responsible for it [3]. The prevalence of PEM increases with age and the number of comorbidities. Thus, as one grows older, the nutrition priorities change is 
often towards meeting increased nutrient needs with reduced energy requirement, and minimizing lean muscle loss $[6,7]$.

The malnutrition affects height, growth, cognitive development, learning ability, social behavior and health of the children making them more prone to infections [8]; even common diseases like influenza can lead to the children's death during PEM [9] The PEM increases susceptibility to diseases because it leads to high expression of arginase from monocytes and macrophages and the arginase, in turn, causes immunosuppression [7, 10]. It is also associated with numerous poor health outcomes, including high health care costs, mortality rates and poor physical functioning in older adults [11].

PEM is one of the three types of malnutrition on the basis of its severity $[12,13]$ Compared to a normal child of the same age and height, the infant experiencing mild and acute PEM has less body weight and signs of wasting respectively, while a stunted child represents the chronic PEM. Acute PEM is the most severe form of malnutrition and can cause death in extreme conditions. Marasmus and kwashiorkor are the two types of acute PEM [14]. Marasmus is the severe form of malnutrition that arises due to inadequate intake of protein and calories and is characterized by emaciation [15, 16]. It is also known as the sickness of weaning and more prevalent in infants below 1 year of age [17, 18]. The marasmus-affected infants lack subcutaneous fat and muscle mass, primarily in the upper limbs and buttocks. The body weight is generally reduced by $60 \%$. These symptoms are also associated with disorders like anemia, hypothermia, hypovolemic shock, ocular and dermal manifestations [19] On the contrary, kwashiorkor arises only due to protein deficiency. A Kwashiorkor-affected infant shows massive edema in hands and feet unlike marasmus [17, 20, 21]. Furthermore, hairy discoloration, fatty liver, electrolyte imbalance, desquamate rash and irritability are also noticeable symptoms [22, 23]. Also, there were more chances of acute respiratory infection, diarrhea and viral infections in the affected children.

The occurrence and severity of PEM in any country are related to its socio-economic development [24] Age group, gender, dietary habits, literacy rate and living conditions essentially affect the predominance of PEM. Also, low birth weight, improper breastfeeding, early or late initiation of complementary diet and incomplete immunization were mainly responsible for malnutrition [9] In terms of gender factor, females were reportedly more prone to PEM than males [17] resulting mainly from lack of attention toward the female children. Age, education, occupation, marital status and economic status of the women significantly regulate the risk of malnutrition. While age and malnutrition were directly related, education and malnutrition maintained an inverse relationship in females of 15-49 years of age [4, 25]. PEM prevalence has been on the high side in the developing countries and can be passed from one generation to the next (World Bank, 2006). Malnourished women or adolescent girls give birth to babies with low birth weight [26]. Studies in Kenya [4] South Africa [27] and Nigeria [28, 29] showed a high prevalence of PEM linked to the lack of proper nutrition, faulty weaning practices, poverty-related issues and poor medical facilities. In Tanzania, the prevalence of chronic malnutrition (stunting) reduced by only $2 \%$ in children under 5 years between 2005 to 2010 while that of acute malnutrition (wasting) increased up to $4.9 \%$ in 2010 including $1.3 \%$ of severe acute malnutrition [30, 31]. According to Tanzania National Nutrition Survey (NNS), to assess nutritional status of children aged 0-59 months and women of 15 to 49 years, the prevalence of acute malnutrition (wasting) rates were equal to or less than that of 2010 in all regions except for Mbeya and Kigoma in which there was an increased prevalence from 1.2 to $2 \%$ and from 3.2 to $3.9 \%$ respectively. Also, although the national prevalence of chronic malnutrition (stunting) was $34.7 \%$, Kigoma was classified among the regions of high prevalence greater than $40 \%$ [32].

This study was therefore aimed at assessing the factors that contribute to the increased prevalence of PEM in children less than five years of age in Kigoma District of Northwestern Tanzania.

\section{Methods}

\subsection{Study Design}

The data was collected using a cross-sectional survey research design with structured questionnaires as the data collection tool.

\subsection{Study Area}

The study conducted at the Kigoma District Hospital in the Northwestern region of Tanzania.

\subsection{Population}

The study participants were women with children under five years of age and residents of Kigoma District.

\subsection{Sample Size}

A process of sampling is necessary due to the large size of the population and the consequent impracticality and prohibitive cost of assessing each member of the population. For this study, 100 women with children under five years of age were considered to form a representative sample.

\subsection{Sampling Technique}

A simple random sampling technique was used in selecting the respondents. Here, we selected a group of subjects (a sample) for study from a large group (a population). Each individual is chosen by chance and each member of the population has an equal chance of being included in the sample.

\subsection{Data Collection}

The data on factors contributing to the prevalence of protein-energy malnutrition in children under five years of 
age was collected using open and closed ended questionnaires.

\subsection{Data Analysis}

The data was analysed with significant difference determined by analysis of variance and Duncan's Multiple Range Test using SPSS 23.0 Software (Statistical Package for Social Sciences, Inc., Chicago, IL, USA).

\subsection{Research Ethics}

To ensure acceptability of the researcher to the community, consent of the administrative authority of the area under study was obtained. Authors received authority letter from Kigoma District Hospital Ethical Committee to conduct the study. Data collected was carefully handled and used for the study.

\section{Results}

\subsection{Demographic Data}

\subsubsection{Age of Respondents}

Table 1. Age Distribution of the Mothers.

\begin{tabular}{lll}
\hline Age in Years & Number of Respondents & Percentage\% \\
\hline $15-24$ & 12 & 12 \\
$25-34$ & 40 & 40 \\
$35-44$ & 24 & 24 \\
$45-54$ & 24 & 24 \\
Total & 100 & 100 \\
\hline
\end{tabular}

According to the table above, many of the respondents (40\%) aged between $25-34$, followed by those with the age range of 35-44 (24\%) and age range of 45-54 (24\%). The young mothers were of age 15-24 (12\%).

\subsubsection{Level of Education of the Respondents}

Table 2. Level of Education of the Mother.

\begin{tabular}{lll}
\hline Education level & Frequency & Percentage (\%) \\
\hline No formal education & 16 & 16 \\
Primary & 20 & 20 \\
Secondary & 24 & 24 \\
Tertiary & 40 & 40 \\
Total & 100 & 100 \\
\hline
\end{tabular}

The table above shows that the majority of the respondents $(40,40 \%)$ had the tertiary status of education, $24(24 \%)$ had the secondary school education, $20(20 \%)$ had a primary level of education and $16(16 \%)$ had no any formal education.

\subsubsection{Marital Status of the Respondents}
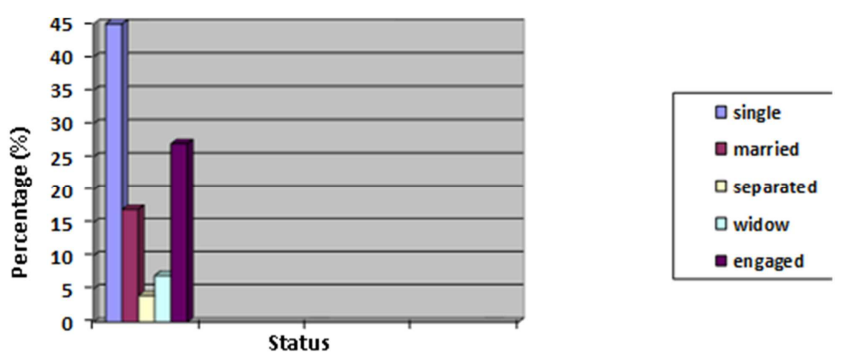

Figure 1. Marital status of the respondents.

From the findings, most of the respondents $(45,45 \%)$ were young single females, followed by the engaged respondents $(27,27 \%)$, the married $(17,17 \%)$, the widowed $(7,7 \%)$ and those who have separated from their partners $(4,4 \%)$.

\subsubsection{Occupation of the Respondents}

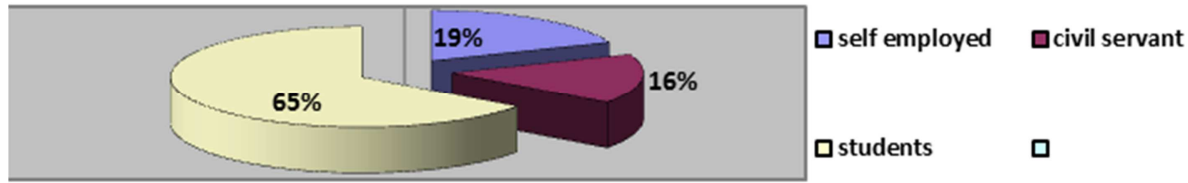

Figure 2. Occupation of the respondents.

Most of the respondents $(65,65 \%)$ were students followed by the self-employed $(19,19 \%)$ and the civil servants $(16$, $16 \%)$.

Table 3. Awareness of the Respondents on the Conditions Causing PEM in Children Under Five Years of Age.

\begin{tabular}{lll}
\hline Conditions & Frequency & Percentage \\
\cline { 2 - 3 } $\begin{array}{l}\text { Lack of iron-rich foods due to poor nutrition, } \\
\text { worms, poverty, ignorance, illiteracy and lack }\end{array}$ & 80 & 80 \\
$\begin{array}{l}\text { of family planning. } \\
\begin{array}{l}\text { Don't know the cause } \\
\text { Total }\end{array}\end{array}$ & 20 & 20 \\
\hline
\end{tabular}

Majority of the respondents $(80,80 \%)$ were aware of causes of PEM in children while only $20(20 \%)$ were not aware of the causes.

\subsection{Health Conditions Present in the Children}

Table 4. General Health Conditions of the Children.

\begin{tabular}{lll}
\hline Conditions & Frequency & Percentage (\%) \\
\hline Malaria & 40 & 40 \\
Diarrheal diseases & 40 & 40 \\
Tuberculosis & 8 & 8 \\
Others & 12 & 12 \\
Total & 100 & 100 \\
\hline
\end{tabular}

The table above shows the occurrence of health conditions in the children. Forty respondents $(40,40 \%)$ had malaria, 40 $(40 \%)$ had diarrhea, $8(8 \%)$ had tuberculosis while those with other conditions were $12(12 \%)$. 
Table 5. Clinical Signs and Symptoms Observed Among the Children.

\begin{tabular}{|c|c|c|}
\hline Signs and Symptoms & Frequency & Percentage \\
\hline 1. Poor weight gain & 54 & 54 \\
\hline 2. Slowing of linear growth & 54 & 54 \\
\hline $\begin{array}{l}\text { 3. Behavioral changes- irritability, apathy, } \\
\text { anxiety and attention deficits. }\end{array}$ & 67 & 67 \\
\hline 4. Anemia & 46 & 46 \\
\hline $\begin{array}{l}\text { 5. Others clinical signs included muscle } \\
\text { wasting, peripheral edema, glossitis, } \\
\text { cheilosis, sparse hair and nail spooning. }\end{array}$ & 65 & 65 \\
\hline
\end{tabular}

According to the clinical presentation, $54 \%$ of the children presented with both poor weight gain and slowing of linear growth, $67 \%$ of the children had behavioral changes, $46 \%$ had anemia and $65 \%$ of the children presented with other signs.

Table 6. Signs and Symptoms of Anemia in the Children.

\begin{tabular}{lll}
\hline Signs and Symptoms & Frequency & Percentage (\%) \\
\hline 1. Pallor & 56 & 56 \\
2. Fatigue & 45 & 45 \\
3. Hemoglobin level $(\mathrm{Hb})<11.0 \mathrm{~g} / \mathrm{dl}$ & 76 & 76 \\
$\quad$ and $\mathrm{Hb}<7.0 \mathrm{~g} / \mathrm{dl}$ & & 56 \\
4. Dyspnea & 56 & 45 \\
5. Palpitations & 45 & 35 \\
6. Breathless & 35 & 25 \\
7. Numbness & 25 & 40 \\
8. Glossitis & 40 & 45 \\
9. Angular cheilitis and & 45 & 20 \\
10. Restless legs syndrome & 20 & \\
\hline
\end{tabular}

The table above shows some of the signs that might correspond with the anemic condition of the children including the Hemoglobin concentration, pallor and fatigue.

\section{Discussion}

This study involved assessment of factors contributing to the prevalence of protein-energy malnutrition (PEM) in children under 5 years of age in Kigoma District of Northwestern Tanzania. One hundred (100) women of age 15 to 54 years, who were attending Kigoma District hospital and had children under 5 years of age were randomly selected to participate in the study (Table 1).

From Table 2 which shows that most of the respondents (84\%) had at least primary school education, $40 \%$ of which had a tertiary education and only $16 \%$ had no form of formal education, it could be adduced that the respondents might have had certain knowledge about PEM. This was confirmed in Table 3 , where $80 \%$ of the mother respondents were aware of the causes of PEM. A knowledgeable mother knows the kind of food a child is fed on and the importance of feeding a child on a balanced diet. In case of signs and symptoms of PEM, such mother knows where to seek medical assistance, showing that high level of ignorance $[32,33]$ might not be the cause of the high prevalence of PEM in the Kigoma district. This can be supported by the previous report that malnutrition is inversely related to formal education $[4,25]$
High prevalence of PEM in Kigoma District as shown by the clinical signs and symptoms in Table 5 agrees with that of Tanzania National Nutrition Survey (2014) and the symptoms mainly denote acute PEM [14, 16, 21]. The symptoms might be due to generalized infections (Table 4). Following the result in Figure 1 (marital status) which shows that most of the mother respondents $(83 \%)$ were either single mothers, the engaged, the widowed or those who have separated from their partners; while only $17 \%$ were married as well as that of Figure 2 which shows that $84 \%$ of the respondents were either students or self-employed with no proper source of income while only 16\% reported being the civil servants, it can be deduced that rise in PEM prevalence in the Kigoma District was due to poverty as the parents might not be able to take proper care of themselves or their children. Poverty has been shown to increase the prevalence of PEM [16, 28, 29] and it has said that malnourished women give birth to malnourished babies making the malnutrition to pass from generation to generation [26, 34]. Accordingly, infections increase the risk of malnutrition [1,4] and malnutrition also makes the children to be more prone to infection because it causes immunosuppression [7, 8, 10] increased poor health outcomes [11]. Thus, the infections in table 5 could result in PEM or from PEM but they could also exacerbate effects of PEM in the children less than 5 years of age.

The result in table 6 which shows the symptoms associated with anemia such as reduced hemoglobin and the anemia may be a strong indication of malnutrition or PEM [35]. The highest prevalence of anemia occurs in developing countries, particularly among pre-school-aged children and women of reproductive age [36] and the anemia is due to many causes including malnutrition and infection $[35,37]$.

\section{Conclusion}

It can be concluded that the high prevalence of PEM in Kigoma District can be due to the low educational status of mothers resulting in poor nutritional status of their children; and also infections.

\section{Recommendations}

The government should encourage health education on causes, prevention, control and complications of PEM in children under five years of age.

Children should be medically checked regularly.

Use of mosquito nets should be encouraged.

Children should be treated for other conditions like worm infestation etc.

The government should improve socioeconomic of her citizens and eradicate poverty.

\section{Conflict of Interests}

The authors of this manuscript declare that no conflict of interest exists. 


\section{References}

[1] WHO, "Management of the child with a serious infection or severe malnutrition," Geneva: Guidelines for care at the first referral level in developing countries, 2000.

[2] O. Muller, M. Krawinkel, "Malnutrition and health in developing countries," CMAJ. 173: pp. 279-286, 2003.

[3] M. Swaminathan, "Advanced textbook on food and nutrition" (pp. 317-320). Bangalore: Bangalore Printing and Publishing Co. Ltd, 2000.

[4] J. Kotut, S. Wafula, G. Ettyang, G. Mbagaya, "Protein-energy malnutrition among women of child bearing age in semi arid areas of Keiyo District," Kenya. Advances in Life Science and Technology. Vol. 24, pp. 80-91, 2014.

[5] A. Sheetal, V. K. Hiremath, A. G. Patil, S. Sajjansetty, R. Sheetal-Kumar, "Malnutrition and its oral outcome - A review," -Journal of Clinical and Diagnostic Research, vol. 7, no. 1, pp. 178-180, 2013.

[6] E. Agarwal, M. Miller, A. Yaxley, E. Isenring, "Malnutrition in the elderly: A narrative review," Maturitas. https://doi.org/10.1016/j.maturitas, 2013.

[7] K. Corware, V. Yardley, C. Mack, S. Schuster, H. Al-Hassi, S. Herath, P. Kropf, "Protein energy malnutrition increases arginase activity in monocytes and macrophages," Nutrition and Metabolism, vol. 11, no. 1 pp. 51, 2014.

[8] D. Gilgen, C. G. Mascie-Taylor, L. Rosetta, "Intestinal helminth infections, anaemia and labour productivity of female tea pluckers in Bangladesh," Tropical Medicine and International Health. Vol. pp. 6: 449-457, 2001.

[9] M. Subramanian, G. Subrahmanyam G, "Determinants of protein energy malnutrition among rural preschool children, "Journal of Evolution of Medical and Dental Sciences, vol. 2, pp. 9157-9162, 2013.

[10] L. Ma, S. Savory, N. G. Agim, "Acquired protein energy malnutrition in glutaric acidemia," Pediatr Dermatol. Vol. 30 no. 4, pp. 502-4, 2013.

[11] R. Van der Pols-Vijlbrief, H. A. H. Wijnhoven, L. A. Schaap, C. B. Terwee, M. Visser, "Determinants of protein-energy malnutrition in community-dwelling older adults: A systematic review of observational studies," Ageing Research Reviews, vol. 10, pp. 34, 2014.

[12] D. T. Bhutia, "Protein Energy Malnutrition in India: The plight of under five children," Journal of Family Medicine and Primary Care, vol. 3, pp. 63-67, 2014.

[13] N. S. Scheinfeld, A. Lin, A. Mokashi, "Protein-energy malnutrition: Background, pathophysiology, epidemiology," Medscape Reference, 2015.

[14] C. Duggan, J. B. Watkins, W. A. Walker, "Nutrition in pediatrics: Basic science, clinical application," USA: PMPH 2004.

[15] T. E. Forrester, A. V. Badaloo, M. S. Boyne, "Prenatal factors contribute to the emergence of kwashiorkor or marasmus in severe under nutrition: evidence for the predictive adaptation model" PLoS One, vol. 7, no. 4, e35907, 2012.

[16] M. D. O. Monteiro, C. J. Akre, G. Clugston, "Global Database on Child Growth and Malnutrition The worldwide magnitude of protein - energy malnutrition : an overview from the WHO Global Database on Child Growth," Bulletin of the World Health Organization, (December), 2015.

[17] S. Chakraborty, S. B. Gupta, B. Chaturvedi, S. K. Chakraborty, "A study of protein energy malnutrition (PEM) in Children ( 0 to 6 Year) in a rural population of Jhansi," 2006.

[18] M. N. Spoelstra, A. Mari, M. Mendel, "Kwashiorkor and marasmus are both associated with impaired glucose clearance related to pancreatic beta-cell dysfunction" Metabolism. $J$ Gastroenterol Hepatol" vol. 23, no. 2, pp. 22-6, 2012.

[19] M. De Onis, C. Monteiro, J. Akre, G. Glugston, "The worldwide magnitude of protein-energy malnutrition: an overview from the WHO global database on child growth," Bulletin of the World Health Organization, vol. 71, pp. 703-712, 1993.

[20] A. V. Badaloo, T. Forrester, M. Reid, F. Jahoor, "Lipid kinetic differences between children with kwashiorkor and those with marasmus," American Journal of Clinical Nutrition, vol. 83, pp. 1283-1288, 2006.

[21] A. Raynaud-Simon, C. Revel-Delhom, X. Hebuterne, "Clinical practice guidelines from the French health high authority: Nutritional support strategy in protein-energy malnutrition in the elderly," Clinical Nutrition. vol. 30, no. 3, pp. 312-319, 2011

[22] T. Ahmed, S. Rahman, A. Cravioto, "Oedematous malnutrition," Indian Journal of Medical Research, vol. 130, pp. 651-654, 2009.

[23] M. J. Manary, D. R. Brewster, "Potassium supplementation in kwashiorkor" Journal of Pediatric Gastroenterology and Nutrition, vol. 24, pp. 194-201, 1997.

[24] M. Ezzati, A. D. Lopez, A. Rodgers, S. Vander Hoorn, C. J. Murray, "Comparative risk assessment collaborating group. Selected major risk factors and global and regional burden of disease" Lancet, Vol. 360, pp. 1347-1360, 2002.

[25] S. Nafzger, L. A. Fleury, D. E. Uehlinger, P. Pluss, N. Scura, S. Kurmann, "Detection of malnutrition in patients undergoing maintenance haemodialysis: a quantitative data analysis on 12 parameters" J Ren Care, vol. 41, no. 3, pp. 168-76, 2015.

[26] World Bank, "Mainstreaming nutrition into poverty reduction strategy papers: What does it take? A Review of the Early Experience," The International Bank for Reconstruction and Development/The World Bank 1818H Street, NW Washington, DC 20433, 2006.

[27] M. Faber, F. Wenhold, "Nutrition in contemporary South Africa," Water SA, 33: 393-400, 2007.

[28] N. Nnakwe, "The effect and causes of protein energy malnutrition in Nigerian children," Nutrition Research, vol. 15, pp. 785-794, 1995.

[29] A. C. Ubesie, N. S. Ibeziakor, "High burden of protein-energy malnutrition in Nigeria: Beyond the health care setting" Annals of Medical and Health Sciences Research, vol. 2, pp. 66-69, 2012.

[30] World Health Organization, "Global Database on Child Growth and Malnutrition," United Republic of Tanzania, Child malnutrition estimates by WHO Child Growth Standards. Retrieved from http://www.who.int/nutgrowthdb/database/countries/tza/en/, 2014. 
[31] National Bureau of Statistics (NBS) [Tanzania], \& ICF Macro, "Tanzania Demographic and Health Survey 2010" Dar-EsSalaam, Tanzania: NBS and ICF Macro, 2011.

[32] M. Halder, S. Q. Halder, “Assessment of protein calorie malnutrition. Clinical Chemistry, vol. 30, pp. 1266-1299, 1984.

[33] National Nutrition Survey, "Report of the National Nutrition Survey" Singapore 2014. Research \& Strategic Planning Division, Health Promotion Board, 2014.

[34] H. Tilg, A. R. Moschen, "Malnutrition and microbiota--a new relationship? Nature Reviews," Gastroenterology and Hepatology, vol. 10, no. 5, pp. 261-2, 2013.
[35] N. M. Mehta, M. R. Corkins, B. Lyman, A. Malone, P. S. Goday, L. Carney-Nieman, W. F. Schwenk, "Defining Pediatric Malnutrition," Journal of Parenteral and Enteral Nutrition, 37(4): 460-481, 2013.

[36] A. R. Aurelie, G. K. Ahou-Yah, G. A. Lukas, G. Dominik, F. H. Richard, K. N. Eliezer, N. Sebastien, W. Rita, U. Jürg, "Etiology of Anemia Among Infants, School-Aged Children, and Young Non-Pregnant Women in Different Settings of South Central Cote d'Ivoire," Am. J. Trop. Med. Hyg, vol. 87, no. 3, pp. 425-434, 2012.

[37] Z. A. Bhutta, R. A. Salam, "Global nutrition epidemiology and trends," Ann Nutr Metab. 61(Suppl 1), pp. 19-27, 2012. 